UDC $54756+544.72$

\title{
SOME ACETOPHENONE DERIVATIVES AS CORROSION INHIBITORS
}

\author{
I.G. Mamedov, I.M. Shikhaliyeva, Y.V. Mamedova, Sh.Z. Gasimova, A.M. Maharramov \\ Baku State University \\ Z.Xalilov str., 23, Baku AZ 1148, Azerbaijan Republic \\ e-mail: bsu.nmrlab@mail.ru, bsu.nmrlab@mail.ru, mamedova_yegane75@mail.ru, \\ ib.nmrlab@list.ru
}

Received 11.05.2019

\begin{abstract}
The inhibition activities of 2-hydroxy-5-methylacetophenone thiosemicarbazone (1), (Z)-2-((E)-1-(2-hydroxy-5-methylphenyl)ethylidene)hydrazono)thiazolidin-4-one (2), (E)-3-(2hydroxy-5-((E)-phenyldiazenyl)phenyl)-1-phenylprop-2-en-1-one (3), (E)-1-(4-bromophenyl)-3(2-hydroxy-5-((E)-phenyldiazenyl)phenyl)prop-2-en-1-one $\quad(4), \quad(E)-5-(2-h y d r o x y-5-$ (phenyldiazenyl)phenyl)-3-phenyl-4,5-dihydro-1H-pyrazole-1-carbothioamide (5), (E)-3-(4-bromophenyl)-5-(2-hydroxy-5-(phenyldiazenyl)phenyl)-4,5-dihydro-1H-pyrazole-1-carbothioamide (6), 2,2'-((1E,1'E)-(ethane-1,2-diylbis(azanylylidene))bis(methanylylidene))bis(4-((E)phenyldiazenyl)phenol (7) and 2-((Z)-2-hydroxy-5-((E)-phenyldiazenyl)benzylidene)hydrazine-1carbothioamide (8) were explored by means of weight loss measurements for mild St-3 specimen in brine-kerosene solution. The corrosion rates of the St-3 drops as the inhibitor concentration increases together with increase of inhibition efficiencies. Thermodynamic parameters of adsorption on the St-3 surface at different concentrations were calculated.
\end{abstract}

Keywords: adsorption, corrosion, surface, metal, nuclear magnetic resonance (NMR)

DOI: 10.32737/2221-8688-2019-2-302-309

\section{Introduction}

The acetophenones and their derivatives are important intermediates in organic synthesis. They serve as starting material for the synthesis of variety of heterocyclic compounds of physiological significance. Because of the presence of different functionalities, these compounds confer biological activities, such as antimicrobial, antibacterial, antifungal, anticancer, antitubercular, antiviral, antiinflammatory, and antihyperglycemic [1-12].<smiles>C/C(=N\N=C(N)I)c1cc(C)ccc1O</smiles><smiles>C/C(=N\N=C1/NC(=O)CS1)c1cc(C)ccc1O</smiles><smiles>O=C(/C=C/c1cc(N=Nc2ccccc2)ccc1O)c1ccccc1</smiles><smiles>CN(N=Nc1ccc(O)c(/C=C/C(=O)c2ccc(Br)cc2)c1)c1ccccc1C1CC(c2cc(N=Nc3ccccc3)ccc2O)N(C(N)=S)N1</smiles><smiles>Oc1ccc(N=Nc2ccccc2)cc1C=NCCCN=Cc1cc(N=Nc2ccccc2)ccc1O</smiles><smiles>NC(=S)N/N=C/c1cc(N=Nc2ccccc2)ccc1O</smiles>

Scheme. The molecular structure of acetophenone derivatives 
Also, acetophenones and their derivatives are known to act as corrosion inhibitors in aggressive media [13-17].

In the previous works we informed about the synthesis and NMR investigations of different acetophenone derivatives [1828].
Our goal in this work was to examine inhibition activity of some acetophenone derivatives against corrosion of St-3 specimen immersed into the brine-kerosene solution. The molecular structure of investigated compounds is shown in Scheme.

\section{Results and discussion}

Mild steel is a material frequently used in various areas of industry. But, in contact to the aggressive media, the corrosion process occurs on the steel surfacel. Different organic compounds were used successfully as inhibitors against the corrosion of different type steels and from year to year the interest is still growing in using other inhibitors. Among these compounds, acetophenone derivatives are known as inhibitors in aggressive media [1317].
In this work, the gravimetric measurements are used for St-3 immersed brinekerosene solution as analog of oil contaminated maritime water.

Weight loss measurements. The weight losses of St-3 specimens in brine-kerosene media (with/without additing different alcoholic solutions of analyzed inhibitors) are determined at 5 hour of immersion time and at $25^{\circ} \mathrm{C}$. Values of CR, \% IE are given in Table 1.

Table 1. Variation of corrosion rate $\left(\mathrm{CR}, \mathrm{mg} / \mathrm{cm}^{2} \cdot\right.$ hour$)$, inhibition efficiency (\% IE) of the compounds (1-8) with their different concentrations in weight loss measurements at $300 \mathrm{~min}$ immersion time in $380 \mathrm{ml}$ brine-kerosene-alcoholic solution and at $25^{\circ} \mathrm{C}$

\begin{tabular}{|c|c|c|c|c|c|c|c|c|}
\hline \multirow{2}{*}{$\mathrm{C}_{\text {inh }}, \mathrm{g}$} & \multicolumn{2}{|c|}{ Compound 1 } & \multicolumn{2}{c|}{ Compound 2 } & \multicolumn{2}{c|}{ Compound 3 } & \multicolumn{2}{c|}{ Compound 4 } \\
\cline { 2 - 9 } & $\mathrm{CR}$ & $\mathrm{IE}$ & $\mathrm{CR}$ & $\mathrm{IE}$ & $\mathrm{CR}$ & $\mathrm{IE}$ & $\mathrm{CR}$ & $\mathrm{IE}$ \\
\hline 0.005 & $4.63 \cdot 10^{-5}$ & 49.56 & $3.68 \cdot 10^{-5}$ & 63.73 & $6,57 \cdot 10^{-5}$ & 64 & $5,33 \cdot 10^{-5}$ & 71 \\
\hline 0.01 & $3.35 \cdot 10^{-5}$ & 60.10 & $3.05 \cdot 10^{-5}$ & 79.5 & $5,56 \cdot 10^{-5}$ & 70 & $5,02 \cdot 10^{-5}$ & 73 \\
\hline 0.03 & $3.21 \cdot 10^{-5}$ & 68.31 & $1.88 \cdot 10^{-5}$ & 91.56 & $4,64 \cdot 10^{-5}$ & 75 & $1,85 \cdot 10^{-5}$ & 90 \\
\hline $\mathrm{C}_{\text {inh }}, \mathrm{g}$ & $\mathrm{Compound} \mathbf{5}$ & \multicolumn{2}{|c|}{ Compound $\mathbf{6}$} & $\mathrm{Compound} \mathbf{7}$ & \multicolumn{2}{c|}{ Compound $\mathbf{8}$} \\
\cline { 2 - 10 } & $\mathrm{CR}$ & $\mathrm{IE}$ & $\mathrm{CR}$ & $\mathrm{IE}$ & $\mathrm{CR}$ & $\mathrm{IE}$ & $\mathrm{CR}$ & IE \\
\hline 0.005 & $1,11 \cdot 10^{-5}$ & 40 & $3,94 \cdot 10^{-5}$ & 78 & $4,61 \cdot 10^{-5}$ & 75 & $6,03 \cdot 10^{-5}$ & 67 \\
\hline 0.01 & $9,5 \cdot 10^{-5}$ & 48 & $3,79 \cdot 10^{-5}$ & 79 & $3,94 \cdot 10^{-5}$ & 78 & $3,55 \cdot 10^{-5}$ & 80 \\
\hline 0.03 & $8,26 \cdot 10^{-5}$ & 55 & $3,7 \cdot 10^{-5}$ & 80 & $1,08 \cdot 10^{-5}$ & 94 & $2,47 \cdot 10^{-5}$ & 87 \\
\hline
\end{tabular}

* corrosion rate $\left(\mathrm{CR}, \mathrm{mg} / \mathrm{cm}^{2}\right.$ hour), from weight loss measurements of $\mathrm{St}-3$ specimens for blank solution at $300 \mathrm{~min}$ immersion time and at $25^{\circ} \mathrm{C}$ in brine-kerosene solution is $5.41 \cdot 10^{-5}$.

In all cases, increase of inhibitor concentration was accompanied by decrease in the weight loss and rise in \% IE. These results made it possible to infer that compounds $\mathbf{2 , 4}$, 
67 and 8 (especially 2,4 and 7, with their inhibition efficiency above 90\%) under investigations are fairly efficient inhibitors for St-3 specimen in brine-kerosene solution.

Except, as seen from the Table 1, corrosion inhibition efficiency for the compound 7 is higher than other investigated compounds. Note that growing inhibition efficiency for the compound 7 probably is caused by the presence of two symmetrical sorption center and ethylene bridge in the investigated compound.

Also, we have seen from Table 1 that the corrosion inhibition efficiency for the compounds $\mathbf{1}, \mathbf{3}$ and $\mathbf{5}$ is less than the compounds $2,4,6,7$ and 8 . Note that the decrease of inhibition efficiency for these compounds is probably caused by the presence of steric factors in the compound $\mathbf{1}$ (in the previous work [26] we have reported about the possibility of the presence of conformational transitions for in the molecule of the compound $\mathbf{1}$ in solution) and absence of bromine atom in the $\mathbf{3}$ and $\mathbf{5}$.

Acetophenone derivatives like 1-8 can inhibit the steel corrosion in brine-kerosenesolutions due to sorption centers in molecules. Indeed, as we have seen from the obtained re- sults (Table 1), synthesized compounds showed higher inhibition efficiency. Thus, the increase of basicity, among other factors, would be expected to increase the inhibition efficiency. Thermodynamic parameters for adsorption of the compounds 1-8 on St-3 surface at 5 hour immersion time in brine-kerosene solution at different concentrations are given in Table 2.

It is well known that values of $\Delta \mathrm{G}_{a d s}^{0}$ -

$20 \mathrm{~kJ} / \mathrm{mol}$ or lower indicate a physical adsorption while those more negative than $-40 \mathrm{~kJ} / \mathrm{mol}$ involve sharing or transfer of electrons from inhibitor molecules to the metal surface to form a coordinate type of bond (chemical adsorption). The possible adsorption mechanism are: (i) electrostatic interaction between the charged inhibitor molecules and charged steel surface (called as physical adsorption, (ii) direct adsorption on the basis of donor-acceptor interactions between the separate pairs of electrons of hetero-atoms, p-electrons of benzene and heterocyclic rings and the vacant $\mathrm{d}$ orbitals of iron surface atoms (called as chemical adsorption [29, 30].

Table 2. Thermodynamic parameters for adsorption of 1-8 $(0.005,0.01,0.03 \mathrm{~g}$ in $380 \mathrm{ml})$ on St-3 surface at $300 \mathrm{~min}$ immersion time in brine-kerosene-alcoholic solution at different concentrations

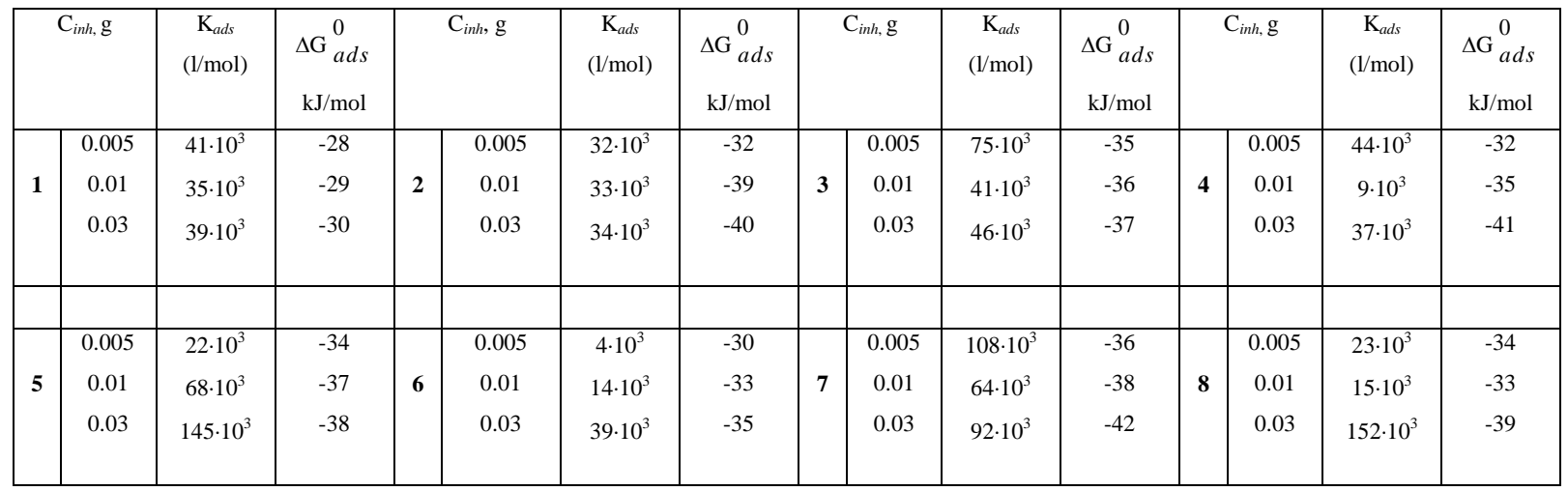

As is seen from the Table 2, the $\Delta \mathrm{G}_{a d s}^{0}$ value for the compounds $2,4,6,7$ and 8 in high concentrations clearly indicates its chemical adsorption(-39, $-40,-41$ and $-42 \mathrm{~kJ} / \mathrm{mol})$; however, in low concentrations it indicates complex sorption on the steel surface. The range of calculated $\Delta \mathrm{G}_{a d s}^{0}$ values for the compounds 1, 3 and 5 vary between -30 and -38 $\mathrm{kJ} / \mathrm{mol}$. That means that adsorption of these inhibitors on the steel surface could involve complex interactions (physical adsorption and chemical adsorption). 


\section{Conclusions}

The explored compounds are efficiegin $1000 \mathrm{ml}$ ).

inhibitors (especially compounds 2, 4 and 7) against corrosion of St-3 in brine-kerosene solution as analog of aggressive oil contaminated in maritime water. The inhibitor efficiency increased at higher concentrations of inhibitors and good inhibition effect is observed at indicated concentration $(30 \mathrm{mg}$ in $380 \mathrm{ml}$ or 78.95
Rise in inhibition efficiency for the compound $\mathbf{7}$ is probably is caused by the presence of symmetrical sorption center and ethylene bridge in the analyzed molecule.

Obtained results show that the analyzed compounds are good inhibitors in aggresive medium.

\section{Experimental}

All the chemicals were obtained from commercial sources (Aldrich) and used as received.

NMR experiments were performed on a BRUKER FT NMR spectrometer (UltraShieldTM Magnet) AVANCE $300(300.130 \mathrm{MHz}$ for ${ }^{1} \mathrm{H}$ and $75.468 \mathrm{MHz}$ for ${ }^{13} \mathrm{C}$ ) with a BVT 3200 variable temperature unit in $5 \mathrm{~mm}$ sample tubes using Bruker Standard software (TopSpin 3.1). The ${ }^{1} \mathrm{H}$ and ${ }^{13} \mathrm{C}$ chemical shifts were referenced to internal tetramethylsilane (TMS); the experimental parameters for ${ }^{1} \mathrm{H}$ : digital resolution $=0.23 \mathrm{~Hz}, \mathrm{SWH}=7530 \mathrm{~Hz}$, $\mathrm{TD}=32 \mathrm{~K}, \mathrm{SI}=16 \mathrm{~K}, 90^{\circ}$ pulse-length $=10$ $\mu \mathrm{s}, \mathrm{PL} 1=3 \mathrm{~dB}, \mathrm{~ns}-=1, \mathrm{ds}=0, \mathrm{~d} 1=1 \mathrm{~s}$; for ${ }^{13} \mathrm{C}$ : digital resolution $=0.27 \mathrm{~Hz}, \mathrm{SWH}=17985$ $\mathrm{Hz}, \mathrm{TD}=64 \mathrm{~K}, \mathrm{SI}=32 \mathrm{~K}, 90^{\circ}$ pulse-length $=$ $9 \mu \mathrm{s}, \mathrm{PL} 1=1.5 \mathrm{~dB}, \mathrm{~ns}=100, \mathrm{ds}=2, \mathrm{~d} 1=3 \mathrm{~s}$. NMR-grade DMSO- $\mathrm{d}_{6}(99.7 \%$, containing $\left.0.3 \% \mathrm{H}_{2} \mathrm{O}\right)$ and acetone- $\mathrm{d}_{6}$ were used for the solutions of 1-8.
The synthesis of $\mathbf{1 - 8}$ was prepared by well- known literature methods [31-33].

${ }^{1}$ H NMR spectrum of 1 (DMSO-d 6$): 1.8$ $\mathrm{s}\left(3 \mathrm{H}, \mathrm{CH}_{3}\right), 2.1 \mathrm{~s}\left(3 \mathrm{H}, \mathrm{CH}_{3}\right), 7.2-7.6 \mathrm{~m}(3 \mathrm{H}$, arom.), $8.5 \mathrm{~s}\left(2 \mathrm{H}, \mathrm{NH}_{2}\right), 10.5 \mathrm{~s}(1 \mathrm{H}, \mathrm{OH}), 11.2$ $\mathrm{s}(1 \mathrm{H}, \mathrm{NH})$.

${ }^{1} \mathrm{H}$ NMR spectrum of 2 (DMSO-d $\left.\mathrm{d}_{6}\right): 1.9$ $\mathrm{s}\left(3 \mathrm{H}, \mathrm{CH}_{3}\right), 2.2 \mathrm{~s}\left(3 \mathrm{H}, \mathrm{CH}_{3}\right), 3.6 \mathrm{~s}\left(2 \mathrm{H}, \mathrm{CH}_{2}\right)$, 7.2-7.6 m (3H, arom.), $10.2 \mathrm{~s}(1 \mathrm{H}, \mathrm{NH}), 10.7 \mathrm{~s}$ $(1 \mathrm{H}, \mathrm{OH})$.

${ }^{1} \mathrm{H} N M R$ spectrum of $\mathbf{3}$ (DMSO-d $\left.d_{6}\right)$ : $6.96 \mathrm{~d}(1 \mathrm{H}$, arom. $), 7.36-8.15 \mathrm{~m}(14 \mathrm{H}$, arom. and $\mathrm{CH}=\mathrm{CH})$.

${ }^{1} H$ NMR spectrum of $4\left(D M S O-d_{6}\right)$ : $7.1 \mathrm{~d}$ (1H,arom.), 7.3-8.2 m (13H, arom. and $\mathrm{CH}=\mathrm{CH}), 9.7 \mathrm{~s}(1 \mathrm{H}, \mathrm{OH})$.

${ }^{1} \mathrm{H}$ NMR spectrum of 5 (DMSO-d $\left.d_{6}\right)$ : 3.2-3.9 d $\left(2 \mathrm{H}, \mathrm{CH}_{2}\right), 5.9 \mathrm{~m}(1 \mathrm{H}, \mathrm{CH}), 6.7 \mathrm{~d}$ $(1 \mathrm{H}$, arom. $), 7.1-7.8 \mathrm{~m}(12 \mathrm{H}$, arom. $), 9.9 \mathrm{~s}(1 \mathrm{H}$, $\mathrm{OH})$.

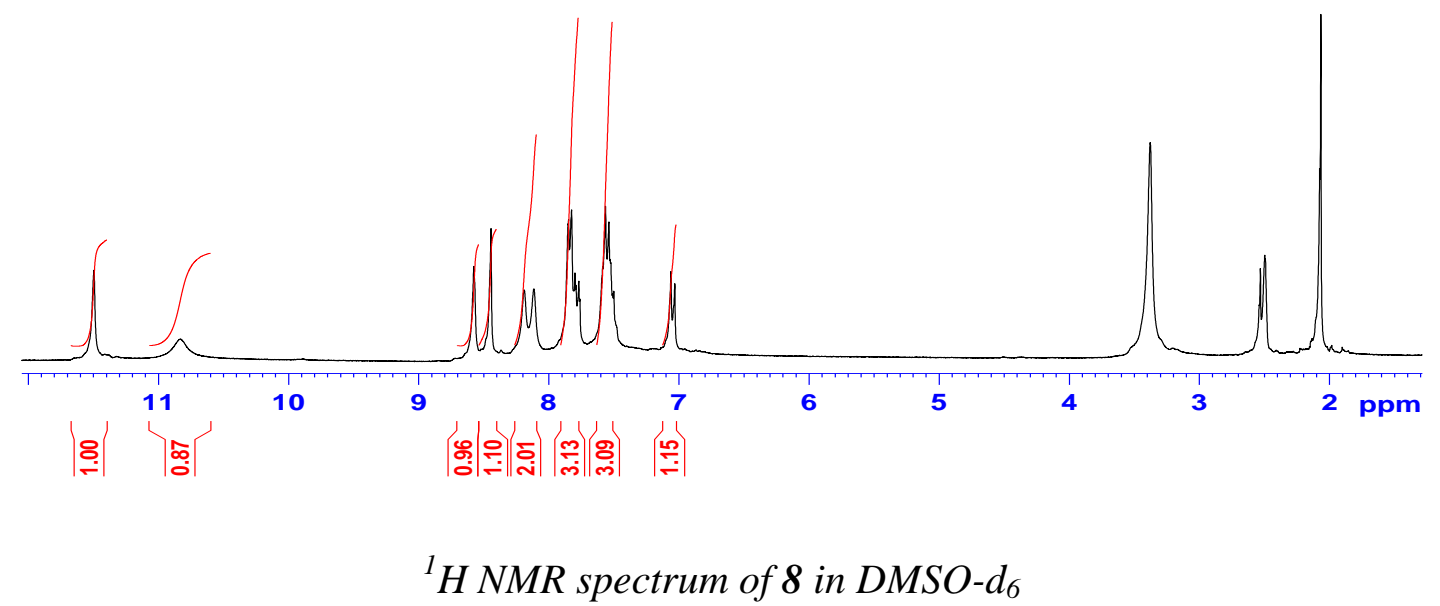


${ }^{1} \mathrm{H}$ NMR spectrum of $6\left(D M S O-d_{6}\right): 3.3-4.0 \mathrm{~d}$ $\left(2 \mathrm{H}, \mathrm{CH}_{2}\right), 6.1 \mathrm{~m}(1 \mathrm{H}, \mathrm{CH}), 6.71 \mathrm{~d}(1 \mathrm{H}$, arom. $)$, 7.4-7.9 m (11H, arom.), $9.9 \mathrm{~s}(1 \mathrm{H}$, arom. $)$.

${ }^{1} \mathrm{H} N M R$ spectrum of $7\left(D M S O-d_{6}\right): 3.7$

s (2H, arom.), 6.9d (2H,arom.), 7.3-7.9 m

(12H, arom.), $8.2 \mathrm{~s}(2 \mathrm{H}$, arom. $), 9.6 \mathrm{~s}(2 \mathrm{H}$, $\mathrm{CH}=\mathrm{N}), 10.9 \mathrm{~s}(2 \mathrm{H}, \mathrm{OH})$.

${ }^{1} \mathrm{H} N M R$ spectrum of $8\left(D M S O-d_{6}\right): 6.9$ $\mathrm{d}(1 \mathrm{H}$, arom.), 7.2-7.4m (3H, arom.), 7.7-7.9 m $(3 \mathrm{H}$, arom.), $8.3 \mathrm{~s}(1 \mathrm{H}$, arom. $), 9.2 \mathrm{~s}(1 \mathrm{H}$, $\mathrm{CH}=\mathrm{N}), 9.8 \mathrm{~s}(1 \mathrm{H}, \mathrm{OH})$.

The composition (wt \%) of steel-3 specimen used for all experiments is as follows: (0.14$0.22 \%$ C, $0.05-0.17 \%$ Si, $0.4-0.65 \% \mathrm{Mn}, 0.3 \%$ $\mathrm{Ni}, 0.3 \%, \mathrm{Cu}, 0.3 \% \mathrm{Cr}, 0.08 \%$ As, $0.05 \% \mathrm{~S}$ and $0,04 \% \mathrm{P}$ and the remainder iron), are abraded with different emery paper up to 1200 grade, washed thoroughly with bidistilled water, degreased and dried with acetone.
The aggressive corrosion medium is prepared in a 7:3 water/ethanol mixture (245:105 ml) for complete solubilization plus $30 \mathrm{ml}$ kerosene and $12 \mathrm{~g} \mathrm{NaCl}$ with the following inhibitor concentrations: 0 (blank), 0.005, $0.01,0.03 \mathrm{~g}$ in $380 \mathrm{ml}$. Gravimetric measurements are carried out in terms of absence/presence of chalcones (or isoxazoles) in $500 \mathrm{ml}$ glass flask supplied with a mixer. Finely abraded and dried mild steel specimens of dimension $2.39 \mathrm{~cm} \times 1.89 \mathrm{~cm} \times 0.37 \mathrm{~cm}$ were weighed on a digital balance with sensitivity of $0.00001 \mathrm{~g}$.

The effect of acetophenone derivative addition is tested at different concentrations on the corrosion of St-3 in brine-kerosene solution and explored through weight loss analysis at $298 \mathrm{~K}$ after $5 \mathrm{~h}$ of immersion period.

\section{References}

1. Nowakowska Z., Kedzia B., Schroeder G. Synthesis, physicochemical properties and antimicrobial evaluation of new $(E)$ chalcones, Eur. J. Med. Chem. 2008, vol. 43, pp. 707-713.

2. Mishra N., Arora P., Kumar B., Mishra L.C., Bhattacharya A., Awasthi S.K., Bahsin V.K. Synthesis of novel substituted 1,3-diaryl propenone derivatives and their antimalarial activity in vitro, Eur. J. Med. 2008, vol. 43, pp. 1530-1535.

3. Yar M.S., Siddiqui A.A.,.Ali M.A. Synthesis and antimycobacterial activity of novel heterocycles, J. Serb. Chem. Soc. 2007, vol. 72, pp. 5-12.

4. Doan T.N., Tran D.T.. Synthesis, Antioxidant and Antimicrobial Activities of a Novel Series of Chalcones, Pyrazolic Chalcones, and Allylic Chalcones, J. Pharm. \& Pharmacy. 2011, vol. 2, pp. 282-288.

5. Dong X., Liu T., Yan J., Yiang C., Chen J., Liu T., Hu J. Identification of SVM-based classification model, synthesis and evaluation of prenylated flavonoids as vasorelaxant agents, Bioorg. Med. Chem. 2008, vol. 16, pp. 8151-8150.

6. Patil S.G., Utale P.S., Gholse S.B., Thakur S.D., Pande S.V.J. Synthesis, characteriza- tion and antimicrobial activity of 6-bromo4-methoxy4-(substituted phenyl) iminoflavone, Chem. and Pharm. Research. 2012, vol. 4, pp. 501-507.

7. Katade S., Phalgune U., Biswas S., Wakhardar R., Deshpandey N. Microwave studies on synthesis of biologically active chalcone derivatives, Ind. J. Chem. 2008, vol. 47B, pp. 927-931.

8. Khatib S., Nerya O., Musa R., Shmuel M., Tamir S., Vaya J. Chalcones as potent tyrosinase inhibitors: the importance of a 2,4substituted resorcinol moiety, Bioorg. Med. Chem. 2005, vol. 13, pp. 433-441.

9. Sharma V., Sharma K.V. Synthesis and biological activity of some 3,5diarylisoxazoline derivatives: reaction of substituted chalcones with hydroxylamine hydrochloride, 2010, E-Jour. Chem. vol. 7, pp. 203-209.

10. Hsieh H.K., Tsao L.T., Wang J.P., Lin C.N., Synthesis and antiinflammatory effect of chalcones, J. Pharm. Pharmacol. 2000, vol. 52, pp. 163-171.

11. Ram V.J., Saxena A.S., Srivastava S., Chandra S. Oxygenated chalcones and bischalcones as potential antimalarial 
agents, Bioorg. Med. Chem. Lett. 2000, no.10, pp. 2159-2161.

12. Dhar D.N. The chemistry of chalcones and related compounds. Wiley, New York, 1981. $285 \mathrm{p}$.

13. Bouklah M., Hammouti B., Aouniti A., Benkaddour M., Bouyanzer A. Synergistic effect of iodide ions on the corrosion inhibition of steel in $0.5 \mathrm{M} \mathrm{H}_{2} \mathrm{SO}_{4}$ by new chalcone derivatives, Appl. Surf. Sci. 2006, vol. 252, pp. 6236-6242.

14. Fouda A.S., Hassan A.F., Elmorsi M.A.,. Fayed T.A, Abdelhakim A. Chalcones as Environmentally-Friendly Corrosion Inhibitors for Stainless Steel Type 304 in 1 M HCl Solutions, Int. J. Electrochem. Sci. 2014, vol. 9, pp. 1298-1320.

15. Fouda A.S., Shalabi K., Elewady G.Y., Merayyed H.F. Chalcone Derivatives as Corrosion Inhibitors for Carbon Steel in 1 M HCl Solutions, Int. J. Electrochem. Sci. 2014, vol. 9, pp. 7038-7058.

16. Singh P., Quraishi M.A., Ebenso E.E., Verma C.B. Ultrasound Assisted Synthesis of Chalcones as Green Corrosion Inhibitors for Mild Steel in 1M Hydrochloric Solution, Int. J. Electrochem. Sci. 2014, vol. 9, pp. 7446-7459.

17. Love R.F., Duranlean R.G., US Pat 4172079. Chem. Abstr, 92, 7648j (1980).

18. Maharramov A.M, Sadikhova N.D., Mammadov I.G., Allakhverdiev M.A. Alkylation of beta-dicarbonyl compounds as a method for the production of functionally substituted dihydrofurans, Chem. Heterocyc. Compound. 2009, vol. 45, pp. 400-404.

19. Mamedov I.G., Eichhoff U., Maharramov A.M., Bayramov M.R., Mamedova Y.V. Molecular dynamics of alkenylphenol derivatives in solution as studied by NMR spectroscopy, Appl. Magn. Reson. 2010, vol. 38, pp. 257-269.

20. Mamedov I.G., Bayramov M.R., Mamedova Y.V., Maharramov A.M. Molecular dynamics of (E)-6-acetyl-3-(2-hydroxy-5methylphenyl)-5-styryl cyclohex-2-en-1- one and (E)-6-ethylcarboxylate-3-(2hydroxy-5-methylphenyl)-5-styryl cyclohex-2-en-1-one in a solution studied by NMR spectroscopy, Magn. Reson. Chem. 2010, vol. 48, pp. 671-677.

21. I.G. Mamedov, U. Eichhoff, A.M.Maharramov, M.R. Bayramov, Y.V. Mamedova, Molecular dynamics of (Z)-1(2-hydroxy-5-methyl-3nitrophenyl)ethanone oxime and (E)-2hydroxy-5-methylacetophenone thiosemicarbazone in solution studied by NMR spectroscopy, Cent. Eur. Jour. Chem. 2012, vol.10, pp. 241-247.

22. Mamedov I.G., Eichhoff U., Maharramov A.M., Bayramov M.R., Mamedova Y.V. Molecular dynamics of cis-1-(2-hydroxy5 -methylphenyl)ethanone oxime and $\mathrm{N}$ (2-hydroxy-4-methylphenyl)acetamide in solution studied by NMR spectroscopy, Magn. Reson. Chem. 2013, vol. 53, pp. 600-604.

23. Mamedov I.G., Bayramov M.R., Mamedova Y.V., Maharramov A.M. New synthesis on the basis 2-allyloxy chalcone and NMR studies its some derivatives, Magn. Reson. Chem. 2015. vol. 53, pp. 141-147.

24. Mamedov I.G., Bayramov M.R., Salamova A.E., Maharramov A.M. NMR studies of some 4-hydroxy-2-methylacetophenone thiosemicarbazones in solutions, Ind. Jour. Chem. 2015, vol. 54B, pp. 15181527.

25. Mamedov I.G., Abbasoglu R., Bayramov M.R., Maharramov A.M. Synthesis of a new 1,2,3,4,5-pentasubstituted cyclohexanol and determining its stereochemistry by NMR spectroscopy and quantumchemical calculations, Magn. Reson. Chem. 2016, vol. 54, pp. 315-319.

26. Mamedov I.G., Mamedova Y.V., Khrustalev V.N., Bayramov M.R., Maharramov A.M. Dependence of biological activities of some chalcone derivatives from the molecular structure, Ind. Jour. Chem. 2017, vol. 56B, pp. 192196. 
27. Mamedov I.G.,,Farzaliyeva A.E, Mamedova Y.V., Hasanova N.N., Bayramov M.R., Maharramov A.M. Antibacterial and antifungal activities of some hydroxyacetophenone derivatives, Ind. Jour. Chem. 2018, 57B, pp. 1310-1314.

28. Maharramov A.M., Mamedova Y.V., Bayramov M.R., Mamedov I.G. Chalcone derivatives as corrosion inhibitors for mild steel in brine-kerosene solution, Russ. Jour. Phys. Chem., 2018, 92, pp. 2154-2158.

29. Bahrami M.J., Hosseini S.M.A., Pilvar P. Experimental and theoretical investigation of organic compounds as inhibitors for mild steel corrosion in sulfuric acid medium, Corros. Sci. 2010, vol. 52, pp. 2793-2803.
30. Ahamad I., Prasad R., Quraishi M.A. Thermodynamic, electrochemical and quantum chemical investigation of some Schiff bases as corrosion inhibitors for mild steel in hydrochloric acid solutions, Corros. Sci. 2010, vol. 52, pp. 933-942.

31. Tietze L.F., Eicher Th., Reaktionen und Synthesen im Organisch-Chemischen Praktikum und Forschungslaboratorium, Stuttgart, New York, Georg Thieme Verlag, $1991.636 \mathrm{p}$.

32. Khodairy A.J. Synthetic studies on the synthesis of some new fused heterocyclic compounds derived from 3,5pyrazolidinedione, Chine Chem. Society. 2007, vol. 54. pp. 93-102.

33. Fieser L. Organic Experiments. D.C. Heath and Company. USA, 1992. 664 p.

\title{
BOZİ ASETOFENON TÖROMOLORİ KORROZIYA INHIBBITORU KIMI
}

\author{
I.G. Mommadov, I.M. Şixaliyeva,Y.V. Mommədova, Ş.Z. Qasimova, A.M. Məhərrəmov \\ Bakı Dövlat Universiteti \\ AZ 1148 Bakn, Z.Xalilov kü̧s., 23; e-mail : bsu.nmrlab@mail.ru, $\underline{\text { bsu.nmrlab@mail.ru, mamedo- }}$ \\ vayegane75@mail.ru, ib.nmrlab@list.ru
}

Taqdim olunan işda 2-hidroksi-5-metilasetofenon tiosemikarbazon (1), (Z)-2-(((E)-1-(2-hidroksi-5-metilfenil)etiliden)hidrazono)tiazolidin-4-on (2), (E)-3-(2-hidroksi-5-((E)-fenildiazenil)fenil)-1-fenilprop-2en-1-on (3), (E)-1-(4-bromfenil)-3-(2-hidroksi-5-((E)-fenildiazenil)fenil)prop-2-en-1-on (4), (E)-5-(2hidroksi-5-(fenildiazenil)fenil)-3-fenil-4,5-dihidro-1H-pirazol-1-karbotioamid (5), (E)-3-(4-bromfenil)-5(2-hidroksi-5-(fenildiazenil)fenil)-4,5-dihidro-1H-pirazol-1-karbotioamid (6), 2,2'-((1E,1'E)-(etan-1,2diilbis(azanililiden))bis(meianililiden))bis(4-((E)-fenildiazenil)fenol (7) vo 2-((Z)-2-hidroksi-5-((E)fenildiazenil)benziliden)hidrazin-1-karbotioamidinin (8) duzlu su-kerosin məhlulunda polad-3 nümunəsinə qarşı korroziya inhibitoru xassasi qravimetrik üsulla tadqiq edilmişdir. Müayyən olunmuşdur ki, inhibitorun qatılı̆̆ artdlqca korroziyanın sürati azalır, inhibitor effekti isa artır.

Açar sözlor: adsorbsiya, korroziya, səth, metal, nüva magnit rezonansı (NMR)

\section{НЕКОТОРЫЕ ПРОИЗВОДНЫЕ АЦЕТОФЕНОНА В КАЧЕСТВЕ ИНГИБИТОРОВ КОРРОЗИИ}

\author{
И.Г. Мамедов, И.М. Шихалиева, Е.В. Мамедова, Ш.З. Касимова, А.М. Магеррамов \\ Бакинский государственный университет \\ AZ 1148 Баку, ул. 3.Халилова, 23; e-mail: bsu.nmrlab@mail.ru, bsu.nmrlab@mail.ru, mamedo- \\ vayegane75@mail.ru, ib.nmrlab@list.ru
}

Ингибиторная активность 2-гидрокси-5-метилащетофенон тиосемикарбазона (1), (Z) -2-(((E)-1(2-гидрокси-5-метилфенил) этилиден)гидразоно)тиазолидин-4-она (2), (E) -3- (2-гидрокси-5 - ((E) - 
фенилдиазенил)фенил) -1-фенилпроп-2-ен-1-она (3), (E) -1- (4-бромфенил) -3- (2-гидрокси-5 - ((E)фенилдиазенил) фенил) проп-2-ен-1-она (4), (E) -5- (2-гидрокси-5- (фенилдиазенил)фенил) -3-фенил4,5-дигидро-1Н-пиразол-1-карботиоамида (5), (Е)-3-(4-бромфенил)-5-(2-гидрокси-5- (фенилдиазенил)фенил)-4,5-дигидро-1Н-пиразол-1-карботиоамида (6), $2,2^{\prime}-\left(\left(1 E, 1^{\prime} E\right)-(э т а н-1,2-\right.$ диилбис(азанилиден))бис(метанилиден))бис(4-((E)-фенилдиазенил)фенол (7) и 2-((Z)-2-гидрокси-5((E)-фенилдиазенил)бензилиден)гидразин-1- карботиоамида (8) была исследована путем измерения потери веса для мягкого образиа стали в солевом растворе вода-керосин. Обнаружено, что с увеличением концентрации ингибитора скорость коррозии Ст-снижается, а эффективность ингибирования увеличивается.

Ключевые слова: адсорбция, коррозия, поверхность, металл, ядерный магнитный резонанс (ЯМР) 